\title{
Elisa Evaluation of the Levels of Antibodies Against Infectious Bronchitis Virus in Laying Hens Using Egg Yolk as Substrate
}

Author(s)

Rauber $\mathrm{RH}^{2}$

Flôres $\mathrm{ML}^{2}$

Pereira $\mathrm{CE}^{3}$

Grigulo $\mathrm{M}^{4}$

Scholarship from BIC/FAPERGS - Laboratório Central de Diagnóstico de Patologias Aviárias/DMVP/CCR/UFSM

2 Prof. Dra. - LCDPA/DMVP/CCR/UFSM

3 Scholar - LCDPA/DMVP/CCR/UFSM

4 Scholar - LCDPA/DMVP/CCR/UFSM

\section{Mail Address}

Laboratório Central de Diagnóstico de Patologias Aviárias - DMVP/CCR/UFSM

Prédio 44, sala 5151

97.105-900

E-mail: rh_rauber@yahoo.com.br

\section{Keywords}

Antibody, egg yolk, ELISA, infectious bronchitis, serology.

\section{ABSTRACT}

The present work was carried out to compare Infectious Bronchitis Virus (IBV) antibody titers in serum and egg yolk samples from laying hens. Sixty paired blood and egg samples were collected from laying hens of two farms. Serum samples were frozen, while egg yolk samples were diluted (1:500) before freezing. Serum and yolk samples were tested for the presence of IBV antibodies by indirect ELISA (commercial kit) and titers were compared by a correlation test $(\alpha=0.05)$. There was a high correlation $(r=0.62)$ between the two kinds of samples, which means that titers of IBV antibodies in the egg yolk and in serum samples are quite the same. Considering that blood collection causes deep stress that leads to economic losses, and since eggs are collected daily on the farm, results reported here are of importance to poultry production.

\section{INTRODUCTION}

Infectious Bronchitis (IB) is a viral disease caused by a coronavirus that might be acute or chronic. It is extremely infectious and affects birds from both sexes and of any breeding purpose. It is the disease that spreads most quickly inside a flock and involves the urinary and reproductive systems in laying hens (Cavanagh \& Naqi, 2003; Di Fábio \& Rossini, 2000).

Antibodies are proteins produced with the purpose of identifying antigens and presenting them to other components of the immunologic system. In birds, antibodies belong to three classes, IgM, IgA and $\lg Y$ (IgG); each class has its own function (Morgulis, 2002). Immunoglobulin $\mathrm{Y}(\mathrm{Ig} Y)$ is the systemic antibody and is thus found in the serum. Besides, it is the smallest antibody and can go throughout any membrane in the host. Therefore, this antibody can be found in the egg yolk and is responsible for passive immunity (Tizard, 1996).

Nowadays, productive parameters must be improved in all segments of the poultry productive chain. Birds are submitted to deep stress when blood samples are collected from flocks, and such practice is done most frequently in laying hens. Furthermore, blood sample collection might also be involved in disease dissemination, such as Avian Leukosis. Considering the great importance of surveillance, methods should be developed in order to collect samples other than blood.

\section{MATERIAL AND METHODS}

Two farms were selected in the region of Salvador do Sul, RS, Brazil. Thirty serum samples and 30 eggs were harvested from each farm. Both samples (egg and serum) were harvested from the same chicken at the same time. This is considered as paired sampling since samples came from the same individual and by different routes. Blood samples were 
centrifuged and serum samples were obtained. Egg yolk samples were diluted as follows: yolk was diluted 10 times (1:10 - solution $A)$ in soap solution. Afterwards, solution A was diluted 50 times (1:50) in serum diluents. This results in a "B solution", which final dilution is 1:500.

Both yolk and serum samples were frozen until analysis. A commercial indirect ELISA kit (IDEXX Laboratories) was used to test the samples, according to the manufacturer's instructions. Antibody titers were compared by a correlation test.

\section{RESULTS AND DISCUSSION}

In both farms, tested samples were positive for antiIBV antibodies. This result was expected since chickens had been vaccinated against this virus. Mean IBV antibody titer in the serum was 3.47 with a variance of 0.15 , whilst mean IBV antibody titer in the yolk was 3.46 with a variance of 0.12 . There was a strong and positive correlation ( $r=0.62$ and $\alpha=0.05)$, which means that antibody titers in egg yolk samples are quite the same as serum antibody titers (Figure 1).

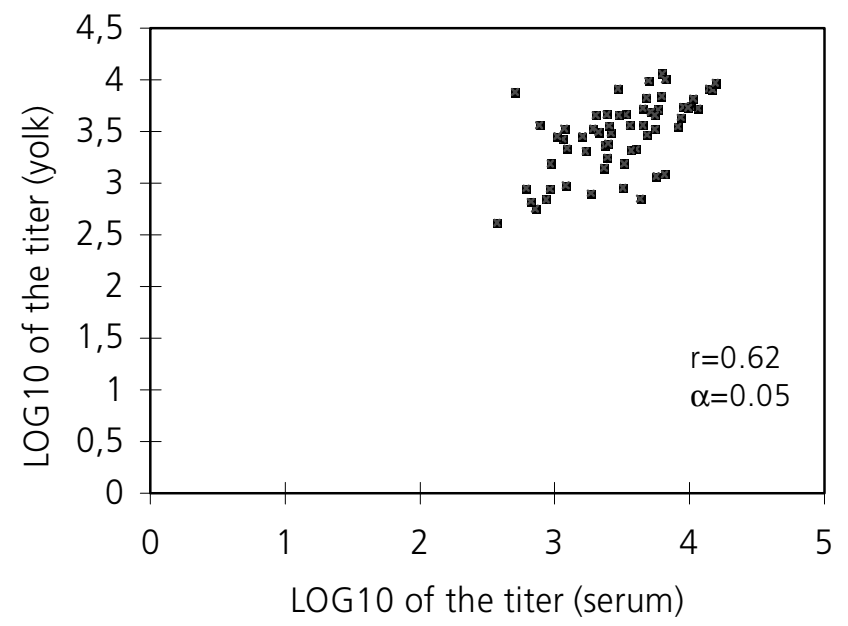

Figure 1 - Correlation between anti-IBV antibody titers in serum and egg yolk samples.

Similar results were described by Fadly \& Payne (2003) using ELISA to test serum, plasma or yolk samples. Silim \& Venne (1989) also described a strong correlation $(r=0.84)$ between antibody titers in yolk and serum of chickens vaccinated against IBV. Keck et al. (1993) reported a moderate correlation (from 0.35 to 0.85 ) between titers found in egg yolk and serum samples against different pathogens. Piela et al. (1984) considered yolk samples as a suitable alternative to serum samples to determine antibodies against IBV, Newcastle Disease Virus (NDV) and Mycoplasma gallisepticum (MG) infections using ELISA.

The findings of this study revealed that the use of egg yolk samples to identify IBV by ELISAs must be diffused, since there are advantages of using such samples, such as: easy collection of the eggs, less stressful to the birds, avoid transmission of diseases and can be used in surveillance studies.

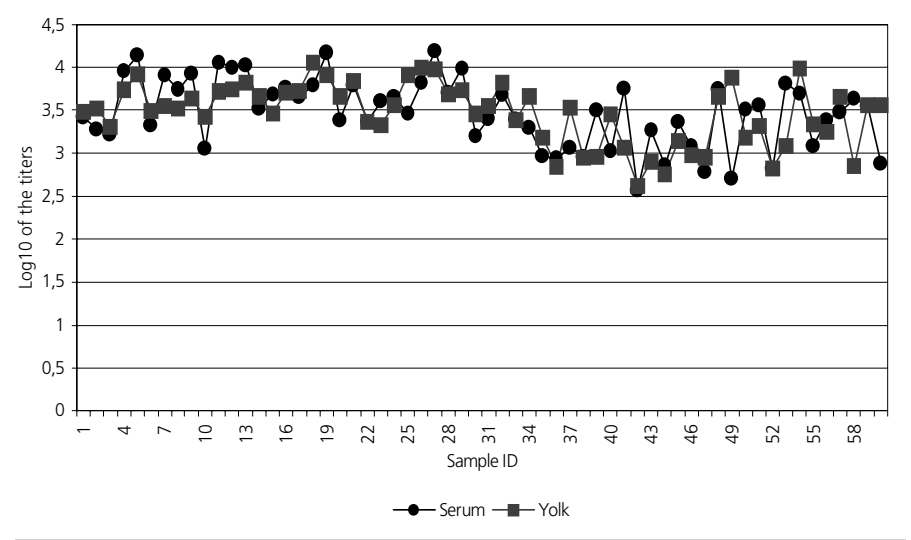

Figure $\mathbf{2}$ - Log10 of antibody titers against IBV in serum and egg yolk samples (paired samples).

\section{CONCLUSION}

The findings of this study revealed that IBV diagnosis could be done by using egg yolk instead of blood samples.

\section{REFERENCES}

Cavanagh D, Naqi SA. Infectious Bronchitis. In: Saif YM, Barnes HJ, Glisson JR, Fadly AM, Mcdougald LR, Swayne DE. Diseases of Poultry. 11 ed. lowa : Iowa State University Press Ames; 2003. p. 101-119.

Di Fábio J, Rossini LI. Bronquite Infecciosa das Galinhas. In: Berchieri Júnior A, Macari M. Doenças das Aves. São Paulo : FACTA. Cap. 5.4. p. 293-300. 2000.

Fadly AM, Payne LN. Leukosis/Sarcoma Group. In: Saif YM, Barnes HJ, Glisson JR, Fadly AM, Mcdougald LR, Swayne DE. Diseases of Poultry. 11 ed. lowa:Iowa State University Press Ames; 2003. p.465516.

Keck LD, Skeeles JK, Mcnew RW. Antibody detection in matched chicken sera and egg-yolk samples by commercial enzyme-linked immunosorbent assay kits for Newcastle diseases virus, infectious bronchitis virus, infectious bursal disease virus and avian reovirus. Avian Diseases 1993; 37(3):825-8. 
Rauber RH, Flôres ML, Pereira CE, Grigulo M
Elisa Evaluation of the Levels of Antibodies Against Infectious Bronchitis Virus in Laying Hens Using Egg Yolk as Substrate

Morgulis MS. Imunologia Aplicada. In: Macari M, Furlan RL, Gonzáles E. Fisiologia Aviária Aplicada a Frangos de Corte. Jaboticabal: FUNEP/UNESP; 2002. p.231-245.

Piela TH, Gulka CM, Yates VJ Chang PW. Use of egg yolk in serological tests (ELISA and $\mathrm{HI}$ ) to detect antibody to Newcastle disease, infectious bronchitis and Mycoplasma gallisepticum. Avian Diseases 1984; 28(4):877-83.

Silim A, Venne D. Comparison of egg-yolk and serum antibody titers to four avian viruses by Enzyme-Linked Immunosorbent Assay using paired field samples. Avian Diseases 1989; 33:643-648.

Tizard IR. Veterinary Immunology: An Introduction. Philadelphia: W.B. Saunders Company. 1996. 531p. 


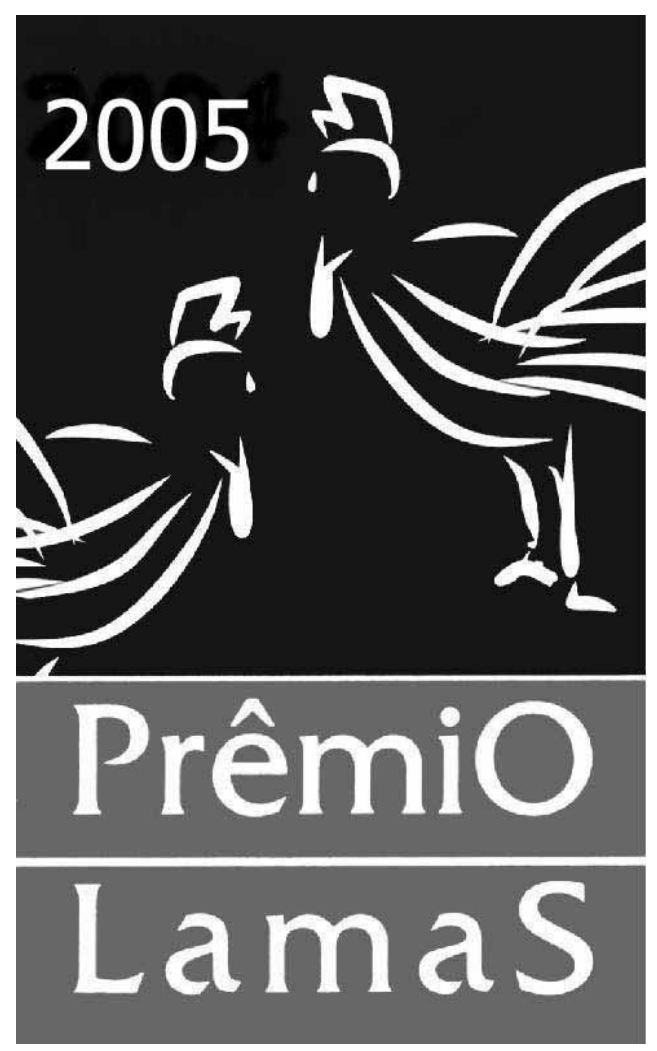

Informamos que em breve as normas e datas para inscrição no Prêmio Lamas'05 estarão disponíveis em nosso site www.facta.org.br 